\title{
FINALITY IN BROWNFIELDS REMEDIATION AND REUSE
}

Joel B. Eisen*

Thirty years after CERCLA's ${ }^{1}$ enactment, the brownfields phenomenon is an anomaly in the statute's complex history. The statute was not designed to address this problem. Instead, as a near-perfect example of the law of unintended consequences, ${ }^{2}$ it arose after CERCLA was in place, and dealt with sites purportedly not contaminated enough to be addressed under it. The statutory net swept in brownfields sites (abandoned or underused properties, mostly in urban areas) along with highly contaminated sites, subjecting them to a fear of liability that hampered remediation and reuse prospects. Since the 1980 s, however, state voluntary cleanup programs (VCPs), federal liability relief, and programs for brownfields developers have promoted redevelopment activities. ${ }^{3}$ After the 2002 Small Business Liability Relief and Brownfields Revitalization Act (SBLRBRA) ${ }^{4}$ added liability protections, ${ }^{5}$ brownfields largely faded from the CERCLA headlines.

* Professor of Law, University of Richmond School of Law. Copyright 2011, all rights reserved.

1. Comprehensive Environmental Response, Compensation, and Liability Act, 42 U.S.C. $\S \S 9601-9675$ (2006).

2. See Tom Rath, Deregulation by Any Other Name: New Jersey's Site Remediation Reform Act in Federal Context, 63 ADMIN. L. REV. 323, 332 (2011) (calling brownfields an "unexpected problem").

3. See Joel B. Eisen, Brownfields at 20: A Critical Reevaluation, 34 FORDHAM URB. L.J. 721, 721-23 (2007) [hereinafter Eisen, Brownfields at 20]; BROWNFIELDS: A COMPREHENSIVE Guide to RedeVeloping Contaminated PRoperty 15 (Todd S. Davis \& Scott A. Sherman eds., 3d ed. 2010) [hereinafter BROWNFIELDS: A COMPREHENSIVE GUIDE].

4. Small Business Liability Relief and Brownfields Revitalization Act of 2002, Pub. L. No. 107-118, 115 Stat. 2356.

5. 42 U.S.C. $\S \S 9604-9605,9607,9622,9628$ (2006). See Joel A. Mintz, New Loopholes or - Minor Adjustments?: A Summary and Evaluation of the Small Business Liability Relief and Brownfields Revitalization Act, 20 PACE ENVTL. L. REV. 405, 405-15 (2002) [hereinafter Mintz, New Loopholes]. The Environmental Protection Agency's All Appropriate Inquiries Final Rule, promulgated in 2005 under the SBRLBRA, protects brownfield developers if they make "all 
Brownfields' dramatic transformations from vacant or blighted sites to centerpieces of redevelopment activities have been core components of urban revitalization efforts. ${ }^{6}$ Thousands of brownfields abandoned for years are now being reborn as industrial, commercial, residential and even recreational sites. Take in a baseball game in Bridgeport, Connecticut ${ }^{7}$ or a soccer match at Red Bull Arena in Harrison, New Jersey, ${ }^{8}$ or shop or work at Potomac Yard in Alexandria, Virginia, ${ }^{9}$ and you are part of brownfields redevelopment in action.

The brownfields "problem" looks to be over, done, finished. Today, it merits little more than a few pages of attention in leading books on CERCLA. ${ }^{10}$ But nothing is ever final in CERCLA, and, to quote Yogi Berra, brownfields "ain't over 'til it's over." Many issues that arose at the outset of heightened concern about brownfields in the 1980s are still present today. By all accounts, many brownfields have not been addressed at all, and states have not done enough to ensure that sites that have been cleaned up don't backslide. ${ }^{12}$ In a parallel to ongoing concerns about CERCLA enforcement, the primary challenge is ensuring that there are proper

appropriate inquiries" (including environmental investigation and remediation activities, if necessary) before acquiring ownership of brownfields sites. See 40 C.F.R. pt. 312 (2012).

6. See U.S. EPA, INVESTING IN PARTNERShIP, POSSIBILITY, AND PEOPLE: A REPORT TO STAKEHOLDERS FROM THE U.S. EPA BROWNFIELDS PROGRAM 31 (2005) [hereinafter EPA, INVESTING IN PARTNERSHIP, POSSIBILITY, AND PEOPLE] (discussing successful revitalization efforts). For a European perspective, see Bernard Vanheusden, Brownfield Redevelopment in the European Union, 34 B.C. ENVTL. AfF. L. ReV. 559 (2007) and Gernot PahleN, RESCUE: REGENERATION OF EUROPEAN SITES IN CITIES AND URBAN ENVIRONMENTS 8 (Sept. 8, 2004).

7. See Brownfields Fact Sheet: Bridgeport's Restored Gateway Leads to a Whole New Impression, U.S. EPA, http://nepis.epa.gov/EPA/html/Pubs/pubalpha_B.html (describing Bridgeport's brownfields redevelopment activities).

8. The Harrison project is one example of New Jersey's Brownfield Development Area (BDA) Initiative, a program that attempts to address multiple brownfields in the same location. See U.S. EPA, STATE BROWNFIELDS AND VOLUNTARY RESPONSE PROGRAMS: AN UPDATE FROM THE STATES 16-17 (2011), available at http://epa.gov/brownfields/state_tribal/update2011/ bf_states_report_2011.pdf [hereinafter EPA, STATE BROWNFIELDS AND VOLUNTARY RESPONSE PRograms]; News Release, N.J. Dep't of Envtl. Protection, Dep Playing Big Role in KickStarting Red Bull Soccer Stadium, Revitalization of Harrison Waterfront (Mar. 23, 2010), available at http://www.nj.gov/dep/newsrel/2010/10_0019.htm.

9. See One and Two Potomac Yard, NAT'L INST. OF BUILDING SCI. (2012), http://www.wbdg.org/references/cs_potomac.php (stating that remediation was overseen by the EPA with a "no further action" letter issued by the EPA and the Virginia Department of Environmental Quality).

10. For example, in JoHn S. APPLEgate \& JAN G. LaItos, ENVIRONMENTAL LAW: RCRA, CERCLA, AND THE MANAGEMENT OF HAZARDOUS WASTE 266-69 (2006), the authors addressed the problem in only four pages.

11. YOGI BERRA, THE YOGI BOOK 157 (1998).

12. See Rath, supra note 2, at 327. 
oversight resources. ${ }^{13}$ It should surprise no one that states often are reluctant to pay much attention to a problem they think they have "solved," even if it is demonstrated that is not completely true. ${ }^{14}$

Environmental justice advocates and others have demonstrated the need to involve the public in planning for the future at brownfields sites, ${ }^{15}$ and while public input is increasingly part of brownfields remediation and reuse, it is not always meaningful. ${ }^{16}$ Another trend of the past two decades is the emergence of a broader land use planning agenda centered on sustainability, and its intersection with brownfields laws and policies. ${ }^{17}$ As one report observes, "Communities will succeed in brownfields revitalization when they consider these properties as community and economic opportunities that happen to have an environmental challenge, and connect brownfields initiatives to their broader community vision and revitalization priorities." 18 This responds in part to the challenge of climate change, which was less well known at the time most VCPs began. To many, brownfields now "take center stage in a sustainable planning strategy of thwarting sprawl, preserving open space, reducing greenhouse gas emissions, and reinvesting in urban areas and their communities." 19

The intersection of brownfields redevelopment and these broader concerns presents a host of issues. Does redevelopment of brownfields connect to a larger vision for the city that links with "smart growth" and climate action goals? Retooling the original developer-centered vision of VCPs to promote broader goals is an ongoing challenge. Has the affected community been involved in planning for brownfields remediation, or has the developer controlled the process? The latter narrows the ability to view

13. See Joel A. Mintz, EPA Enforcement of CERCLA: Historical Overview and Recent Trends, 41 Sw. L. REV. 645, 657-58 (2012).

14. See Eisen, Brownfields at 20, supra note 3, at 722.

15. See generally Clifford Rechtschaffen et al., Environmental Justice: Law, Policy and Environmental Protection, SEATTLE U. SCH. OF LAW LEGAL PAPER SERIES \# 10-24 (2009).

16. See Joel B. Eisen, 'Brownfields of Dreams'?: Challenges and Limits of Voluntary Cleanup Programs and Incentives, 1996 U. ILL. L. REV. 883, 998 (1996) [hereinafter Eisen, Brownfields of Dreams].

17. See John Dernbach, Creating the Law of Environmentally Sustainable Economic Development, 28 PACE ENVTL. L. REV. 614, 615 (2011) (discussing "renewable energy technology, green infrastructure, recycling, brownfield redevelopment, and other forms of more sustainable economic development"); Joel B. Eisen, Brownfields Policies for Sustainable Cities, 9 DUKE ENVTL. L. \& POL'Y F. 187, 189-90 (1999) [hereinafter Eisen, Brownfields Policies for Sustainable Cities].

18. NAT'L ASS'N OF LOCAL GOV'T PROF'LS. \& NE.-MIDWEST INST., UNLOCKING BROWNFIELDS: KEYS TO COMMUNITY REVITALIZATION 6 (2004).

19. Justin B. Hollander et Al., PRINCIPLES OF BROWNFIELd REgENERATION: CleanuP, DESIGN, AND REUSE OF DERELICT LAND 2-3 (2010) [hereinafter HOLLANDER ET AL., PRINCIPLES OF BROWNFIELDS REGENERATION]. 
the project as part of a community-wide plan, and undermines its legitimacy. Finally, if brownfields redevelopment yields benefits, how can we measure success over the long term? Metrics for assessing this are only just now emerging.

As I note in Part III, many key questions have incomplete answers today, and as a result, finality in brownfields remediation and reuse continues to elude us. I draw a number of examples from New Jersey, a Rust Belt state with many brownfields and a complex history of dealing with them. ${ }^{20}$ Recent developments in that state, including a 2009 state statute that privatized cleanups, ${ }^{21}$ and well-publicized funding shortfalls and regulatory errors in $2011,^{22}$ highlight the challenges of contemporary brownfields redevelopment.

\section{THE BROWNFIELDS "PROBLEM"}

"Brownfields" are abandoned or underused sites that the SBLRBRA defines as "real property, the expansion, redevelopment, or reuse of which may be complicated by the presence or potential presence of a hazardous substance, pollutant, or contaminant.",23 The United States has perhaps 400,000 to as many as one million brownfields, ${ }^{24}$ although reliable information is hard to come by. ${ }^{25}$

These sites are found throughout the nation, but urban brownfields such as abandoned steel mills or other manufacturing facilities, and formerly grand railroad stations now idle, ${ }^{26}$ attract the most attention. ${ }^{27}$

20. For discussions of New Jersey's site remediation programs, see generally Alexander Maro, Outsourcing the Filth: Privatizing Brownfleld Remediation in New Jersey, 38 B.C. ENVTL. AFF. L. REV. 159 (2011); Eisen, Brownfields at 20, supra note 3; Rath, supra note 2, at 336-42.

21. Site Remediation Reform Act of 2009, ch. 60, 2009 N.J. Laws 476 (codified at N.J. STAT. ANN. § 58:10C-1-29 (West Supp. 2012)).

22. See Christopher Baxter, N.J. to shut down state initiative intended to help clean up 'brownfields,' NJ.COM (June 2, 2011 , 7:57 PM), http://www.nj.com/news/index.ssf/2011/06/ nj_to_shut_down_state_initiati_1.html [hereinafter Baxter, N.J. to shut down state initiative].

23. $4 \overline{2}$ U.S.C. $\$ 9 \overline{601(39)(A) ~(2006) . ~}$

24. U.S. GOV'T ACCT. OFFICE, BROWNFIELD REDEVELOPMENT: STAKEHOLDERS REPORT That EPA's Program Helps to RedeVElop Sites, But Additional MEaSures Could COMPLEMENT AGENCY EFFORTS 1 (2004). See also NAT'L ASS'N OF LOCAL GOV'T PROF'LS. \& NE.-MIDWEST INST., supra note 18, at 3; Brownfield Projects, NEW JERSEY ENVIRONMENTAL INFRASTRUCTURE TRUST (2010), http://www.njeit.org/brownfield.htm.

25. See KRIS WERNSTEDT ET AL., RESOURCES FOR THE FUTURE, VOLUNTARY ENVIRONMENTAL Programs AT CONTAMINATED PROPERTIES 17 (2010), available at http://www.rff.org/rff/documents/rff-dp-10-18.pdf [hereinafter WERNSTEDT ET AL., VOLUNTARY ENVIRONMENTAL PROGRAMS]. New Jersey alone may have more than 10,000 brownfields sites. Brownfield Projects, NEW JERSEY ENVIRONMENTAL INFRASTRUCTURE TRUST, supra note 24.

26. See KRIS WERnStedt ET AL., RESOURCES FOR THE Future, ThE BROWNFIELdS PHENOMENON: MUCH Ado ABOUT SOMETHING OR THE TIMING OF THE SHREWD? 7 (2004), 
Some make up a brownfields variant of "orphan sites"28: former owners are gone, and cities or other public entities now own them. ${ }^{29}$ They have often had numerous owners and histories of industrial or commercial use, but have not been touched for years. ${ }^{30}$ Without environmental investigations, it is often difficult to discern the extent of contamination or need for remediation, let alone whether sites would be dangerous enough to qualify for the National Priorities List ("NPL"). ${ }^{31}$

Brownfields sites may have advantages over other locations. They often sit near railroads, highways, other forms of transportation, and the bulk of cities' populations. ${ }^{32}$ Yet developers often have the choice of foregoing them altogether for greenfield sites in suburbs and exurbs. ${ }^{33}$ The cost of redeveloping a brownfield can be higher than that of a greenfield site $^{34}$ This is not universally the case, however. If the greenfield site has been previously developed and requires rehabilitation of its own, that might negate the cost advantage, ${ }^{35}$ and if the infrastructure at the brownfield site is usable, that might help narrow the cost disadvantage. ${ }^{36}$

Brownfields redevelopment has numerous potential benefits. ${ }^{37}$ As the EPA puts it, "Revitalizing brownfield sites creates benefits at the site and

available at $\mathrm{http}: / /$ www.rff.org/rff/documents/RFF-DP-04-46.pdf [hereinafter WERNSTEDT ET AL., THE BROWNFIELDS PHENOMENON].

27. See Eisen, Brownfields at 20, supra note 3, at 725-26.

28. See WernStEdT ET AL., VolunTary ENVIRONMENTAL Programs, supra note 25, at 14-15 (noting that over 50\% of surveyed brownfields were vacant at the time of entry into a VCP).

29. See Justin B. HOLlander, POlluted \& Dangerous: AMERICA's Worst Abandoned Properties and What CAN Be DONE ABout THEM 2-4 (2009).

30. See Eisen, Brownfields at 20, supra note 3, at 725 .

31. See Eisen, Brownfields of Dreams, supra note 16, at 929-30.

32. See Heidi Gorovitz Robertson, One Piece of the Puzzle: Why State Brownfields Programs Can't Lure Businesses to the Urban Cores Without Finding the Missing Pieces, 51 RUtGers L. REV. 1075, 1093.94 (1999); CHARLES BARTSCH, COMING ClEAN FOR ECONOMIC DEVElopMENT: A RESOURCE BOOK ON ENVIRONMENTAL CLEANUP aNd ECONOMIC DEVELOPMENT OPPOR'TUNITIES ch. 1, pt. 1 (1996), available at http://www.nemw.org/ images/stories/documents/cmclean.pdf; Eisen, Brownfields of Dreams, supra note 16, at 890-92.

33. See BROWNFIELDS: A COMPREHENSIVE GUIDE, supra note 3, at 10; Eisen, Brownfields of Dreams, supra note 16, at 891-92.

34. Robert H. Abrams, Superfund and the Evolution of Brownfields, 21 WM. \& MARY ENVTL. L. \& POL'Y REV. 265, 277-281 (1997) (discussing the cost disadvantages of brownfields).

35. James Boyd et al., The Effects of Environmental Liability on Industrial Real Estate Development, 12 J. REAL EST. FIN. \& ECON. 37, 37-38 (1996).

36. Evans Paull, The Environmental and Economic Impacts of Brownfields Redevelopment, 32 (NE-Midwest Inst., Working Draft for Distribution, July 2008), available at http://www.nemw.org/images/stories/documents/EnvironEconImpactsBFRedev.pdf.

37. See, e.g., Judith Auer Shaw et al., MEASURING Brownfield Success IN NEW JERSEY: HOW DATA INCREASES OUR COMPETITIVE EDGE 20-22 (2008), available at http://www.policy.rutgers.edu/brownfields/projects/success.pdf. 
throughout the community.,"38 Building on urban sites, with their existing footprints and infrastructure, can alleviate sprawl by decreasing the need to consume greenfield lands. ${ }^{39}$ According to a 2001 study, redeveloping one acre of brownfields can conserve as much as an average of 6.2 acres of greenfields. ${ }^{40}$ Brownfield redevelopment can be an effective component of a climate change policy if it spurs a decrease in commuting and therefore in vehicle miles traveled ${ }^{41}$ as transportation accounts for the nation's second largest share of GHG emissions. ${ }^{42}$ Other potential benefits include reductions in storm water runoff and air pollution, ${ }^{43}$ and increased property values in neighboring areas. ${ }^{44}$ At five revitalized sites, the EPA found a 32 to 57 percent reduction in vehicle miles traveled, a 47 to 62 percent reduction in storm water runoff, and a 2-3 percent increase in adjacent property values. ${ }^{45}$

In the mid- to late-1980s, some began to argue that a major challenge to brownfields redevelopment (and perhaps the most prominent one) was the stigma from the possible presence of environmental contamination. ${ }^{46} \mathrm{~A}$ 1992 Congressional field hearing in Ohio saw the first use of the term "brownfield," reform to CERCLA and other laws was indispensable to removing the "brown" stigma. ${ }^{48}$ This fear of liability was overstated, as it turned out that the vast majority of brownfields sites were not contaminated enough to

38. The EPA Brownfields Program Reduces Widespread Environmental and Economic Benefits, U.S. EPA (Sept. 2012), http://www.epa.gov/brownfields/overview/Brownfields-Benefitspostcard.pdf [hereinafter EPA, Brownfields Benefits].

39. See Jonathan P. Deason et al., Public Policies and Private Decisions AFFECTING THE REDEVELOPMENT OF BROWNFIELDS: AN ANALYSIS OF CRITICAL FACTORS, RELATIVE WEIGHTS AND AREAL DIFFERENTIALS $\S 8.1$ (2001), available at http://www.gwu.edu/ eem/Brownfields/project_report/report.htm; Eisen, Brownfields at 20, supra note 3 , at 750 ; Paull, supra note 36 , at 5.

40. DEASON ET AL., supra note 39 , at $\$ 5.3$.

41. See Paull, supra note 36 , at 5 .

42. DAVid L. GREenE \& AndREas Schafer, Reducing GREEnhouse Gas Emissions FROM U.S. TRANSPORTATION 2 (2003), available at http://www.c2es.org/docUploads/reducingtransportation-ghg.pdf.

43. Paull, supra note 36 , at $17-20$; NAT'L ASS'N OF LOCAL GOV'T PROF'LS. \& NE.MIDWEST INST., supra note 18 , at 101, 104.

44. Paull, supra note 36 , at 29-30.

45. EPA, Brownfields Benefits, supra note 38.

46. See BROWNFIELDS: A COMPREHENSIVE GUIDE, supra note 3, at 7-8.

47. Office of Health, Safety \& Sec., U.S. Dep't of Energy, The Brownfields Solution, OPERATING EXPERIENCE SUMMARY 3, 1 (Feb. 28, 2009), http:/www.hss.energy.gov/sesa/ analysis/oesummary/oesummary2009/2009-02-03.pdf; Jonathan D. Weiss, Local Governance, in STUMBling TOWARD SUSTANABILITY 683, 683 (John C. Dembach ed., 2009) ("The word 'brownfields' was not even in the dictionary in 1992; it achieved that honor in 1999.").

48. See BARTSCH, supra note 32 , at ch. 1 , pt. 1 . 
wind up on the NPL. ${ }^{49}$ It also gave CERCLA greater prominence than it deserved among other barriers to urban redevelopment, such as changes in consumer preferences or residential patterns. ${ }^{50}$

Still, there was something to the fear of liability. Throughout the 1980 s, courts gave the EPA more power under CERCLA to investigate and remediate sites, and to the EPA and private parties to fasten liability on PRPs. ${ }^{51}$ CERCLA's broad liability provisions capture a wide group of entities, whether or not they did any actual waste dumping. Attempting to evaluate brownfield sites might subject developers to liability because owners and "operators" are jointly and severally liable under CERCLA, whether or not they owned the sites at the time of disposal. ${ }^{52}$ Therefore, assuming serious contamination was discovered, a developer might face the full price tag of CERCLA remediation even if it did nothing to cause the contamination there. ${ }^{53}$

Developers balked at becoming involved with brownfields, fearing the worst. $^{54}$ Remediation costs could not be quantified ahead of time, ${ }^{55}$ and even after investigations, knowing cleanups' price tags would be difficult. CERCLA cleanups cannot be priced in advance, because remediation is a lengthy process that includes (among other requirements) compliance with ARARs - requirements of other environmental laws. ${ }^{56}$ And if merely investigating the conditions at a brownfield site, let alone making decisions

49. See BROWNFIELDS: A COMPREHENSIVE GUIDE, supra note 3, at 4-5; Eisen, Brownfields of Dreams, supra note 16, at 901.

50. See SHAW ET AL., supra note 37, at 2-4 (discussing the issue generally and listing the seven principal categories of barriers to brownfields redevelopment found by researchers at George Washington University in 2001).

51. 42 U.S.C. $\$ 9601$ (2006).

52. CERCLA imposes liability on "the owner and operator of a vessel or a facility," which applies to current owners without regard for whether they owned sites at the time of disposal of hazardous substances. 42 U.S.C. $\S 9607(\mathrm{a})(1)$ (2006). See also Eisen, Brownfields of Dreams, supra note 16 , at 901 .

53. See, e.g., United States v. Monsanto Co., 858 F.2d 160, 168 (4th Cir. 1994) ("The plain language of section $107(a)(2)$ extends liability to owners of waste facilities regardless of their degree of participation in the subsequent disposal of hazardous waste."). See also ELIZABETH GLASS GELTMAN, RECYCLING LAND: UNDERSTANDING THE LEGAL LANDSCAPE OF BROWNFIELD DEVELOPMENT 53-54 (2000); Eisen, Brownfields of Dreams, supra note 16, at 901; Robertson, supra note 32, at 1084.

54. See Boyd et al., supra note 35 , at 37 .

55. See BROWNFIEldS: A COMPREHENSIVE GUIDE, supra note 3, at 8-9; Eisen, Brownfields of Dreams, supra note 16 , at 906-07.

56. BROWNFIELDS: A COMPREHENSIVE GUIDE, supra note 3, at 124. See Eisen, Brownfields of Dreams, supra note 16, at 907-09; Robertson, supra note 32, at 1089; NAT'L ASs'N OF LOCAL GOV'T PROF'LS. \& NE.-MIDWEST INST., supra note 18, at 124. 
about how to remediate them, might expose a developer to liability, it was easier to shun the site.

Amendments to CERCLA and EPA policies aimed to lessen developers' burden, but were largely unsuccessful. The 1986 SARA amendments $^{57}$ added an "innocent landowner" defense designed to protect those, like brownfields developers, who purchased sites after waste dumping took place, and were therefore not responsible for contaminating them. ${ }^{58}$ However, this defense was not widely used, because meeting its requirements was difficult. ${ }^{59}$ Those seeking to prove their innocence had to demonstrate that they had engaged in "all appropriate inquiry" before purchasing a site. ${ }^{60}$ Most courts retained liability for prospective purchasers who had not discovered the contamination before purchasing the sites, reasoning they probably had not done enough investigation. ${ }^{61}$

Thus, rather than protect brownfields developers, the innocent landowner defense's shortcomings led many to claim more CERCLA reform was needed. ${ }^{62}$ Brownfields advocates sought partnerships with environmental agencies rather than adversarial enforcement-based relationships, shorter cleanup processes with more certainty (including releases or other forms of indicating that the brownfields purchaser would not face liability), and lesser cleanup standards that in some cases would allow less costly means of addressing contamination at the site (for example, so-called "institutional controls" such as fences and warning signs). ${ }^{63}$

States hit hardest by the recession of the early 1990 s tended to be the ones with the most brownfields. ${ }^{64}$ Difficult economic conditions added to the increasingly widespread concern that CERCLA (and its state analogues

57. Superfund Amendments and Reauthorization Act of 1986, Pub. L. No. 99-499, 100 Stat. 1613 (codified as amended at 42 U.S.C. $\$ 9601$ (2006)).

58. See Susan OPP \& Sarah Hollis, CONTAMINated Properties: History, REgUlations, AND RESOURCES FOR COMMUNITY MEMBERS 6 (U. Louisville Ctr. for Envtl. Pol'y \& Mgmt., 2005).

59. See L. Jager Smith, Jr., CERCLA's Innocent Landowner Defense: Oasis or Mirage?, 18 COLUM. J. ENVTL. L. 155, 156-57 (1993).

60. See id. at 159.

61. See Larry Schnapf, The New "All Appropriate Inquiries" Rule, THE PRACTICAL REAL ESTATE LAWYER, Jan. 2007, at 10.

62. See, e.g., Smith, supra note 59.

63. See Eisen, Brownfields of Dreams, supra note 16, at 948. See also John Pendergrass, Institutional Controls in the States: What Is and Can Be Done to Protect Public Health at Brownfields, 35 CONN. L. REV. 1303, 1304 (2003).

64. See U.S. CONF. OF MAYORS, RECYCLING AMERICA'S LAND: A NATIONAL REPORT ON BROWNFIELDS REDEVELOPMENT 10 (1993-2010) (Nov. 2010), available at http://www. usmayors.org/pressreleases/uploads/november2010bfreport.pdf. 
created in the 1980s) were holding back productive investments. ${ }^{65}$ This prompted calls to remove barriers to redeveloping cities, ${ }^{66}$ in which CERCLA was no longer seen as a force for good, but as one of those barriers. Any remediation and reuse activities at urban brownfields were thought to be preferable to continued neglect, even if they did not comport with CERCLA's rigid remediation requirements. ${ }^{67}$

\section{BROWNFIELDS REDEVELOPMENT IN THE STATES, AND FEDERAL LIABILITY PROTECTION}

While brownfields developers were said to fear CERCLA liability, far more sites were subject to the cleanup requirements of state CERCLA-like analogues. ${ }^{68}$ Several states in the Northeast, including New Jersey, also had separate property transfer laws requiring evaluation (and remediation if necessary) of potentially contaminated sites prior to their transfer. ${ }^{69}$ Given this legal environment, the states became primary drivers for brownfields

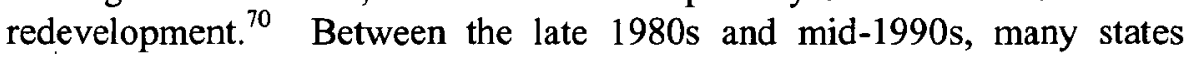
overhauled their environmental cleanup and property transfer laws, creating VCPs to promote brownfields redevelopment. ${ }^{71}$

According to one recent estimate, state VCPs have addressed more than 50,000 brownfields sites, and evaluate another 7,000-8,000 sites each year." "Voluntary" indicates that the process begins when developers approach the states to commence remediation and reuse activities. ${ }^{73}$ The regulatory climate aims to create a working relationship between state regulators and developers, and is sharply different from CERCLA's

65. See Charles Bartsch \& Elizabeth Collaton, Brownfields: Cleaning and REUSING CONTAMINATED PROPERTIES 2, 19 (1997).

66. See BARTSCH, supra note 32 , at ch. 1 , pt. 1. 11.

67. See NAT'L ASS'N OF LOCAL GOV'T PROF'LS. \& NE.-MIDWEST INST., supra note 18, at

68. See WERnStedt ET AL., THE BROWNFIELdS PHENOMENON, supra note 26, at 2; BARTSCH \& COLLATON, supra note 65 , at $5,18$.

69. See Eisen, Brownfields of Dreams, supra note 16, at 915; BROWNFIELDS: A COMPREHENSIVE GUIDE, supra note 3, at 795-96; BARTSCH \& COLLATON, supra note 65, at 17.

70. See BARTSCH \& COLlatON, supra note 65 , at $5,19$.

71. See Eisen, Brownfields at 20, supra note 3, at 721; Maro, supra note 20, at 171-73 (describing New Jersey's program).

72. Paull, supra note 36 , at 5.

73. BROWNFIELDS: A COMPREHENSIVE GUIDE, supra note 3, at 11. See also Eisen, Brownfields of Dreams, supra note 16, at 920-21. 
enforcement-driven model. ${ }^{74}$ VCPs typically include three central attributes: ${ }^{75}$

Streamlined administrative processes: In VCPs, the steps between identification of a site as one to which the program will apply, and final remediation and reuse, are far less in number and shorter in duration than in enforcement-driven models. ${ }^{76}$ Often, developers are put in control of many steps of the process (in some states, by hiring licensed environmental professionals to administer the entire cleanup). ${ }^{77}$

Risk-based cleanup standards: In VCPs, the end use to which sites will be put (such as commercial, industrial, or residential) is factored into the risk assessment of the sites, leading to standards that typically require less than complete remediation. ${ }^{78}$ Often, developers can cut costs by adopting remedies such as entombing soils at brownfield sites rather than removing and treating them. ${ }^{79}$

Liability protection: States offer a number of means for developers to secure protection against future enforcement actions by their environmental agencies, ranging from "no further action" letters (statements of intent that developers would not face liability in the future) to full releases from liability. ${ }^{80}$

In states such as New Jersey, licensed environmental professionals often decide cleanup levels within defined parameters. ${ }^{81}$ New Jersey's 2009 Site Remediation Reform Act ended the previous Voluntary Cleanup Program and devolved cleanup decisions to licensed professionals. ${ }^{82}$ Licensed professionals may issue "Remedial Action Outcome" documents certifying completion of remediation activities without prior approval from

74. See David A. Dana, State Brownfields Programs as Laboratories of Democracy?, 14 N.Y.U. ENVTL. L.J. 86 (2005).

75. Eisen, Brownfields of Dreams, supra note 16, at 886-87; Robertson, supra note 32 , at 1101-07. BROWNFIELDS LAW AND PRACTICE: THE CleANUP \& REDEVELOPMENT OF CONTAMINATED LAND (Michael B. Gerrard ed., 2006) contains a list of individual state programs.

76. See Eisen, Brownfields of Dreams, supra note 16, at $920 \mathrm{n} .180,970$.

77. Id. at 965-70; Maro, supra note 20, at 181.

78. Eisen, Brownfields of Dreams, supra note 16, at 936-38.

79. Id. at 948 .

80. Id. at $950-58$.

81. See Brownfield Site Contamination, N.J. INST. OF TECH., http://www.njit.edu/ tab/managing/pre-development/contamination-investigation.php (last visited Oct. 22, 2012).

82. See Maro, supra note 20, at $180-82$ (describing the Licensed Site Remediation Professionals scheme); JAMES PETERSON, THE ROLE OF THE LicEnSED Site Remediation PROFESSIONALS (2011), available at http://www.slideshare.net/JamesPetersonLSRP/the-role-ofthe-lsrp-in-brownfields-remediation. 
the Department of Environmental Protection. ${ }^{83}$ This process takes these critical decisions out of the hands of state environmental authorities, and relies on quality control of the professionals to ensure proper results. ${ }^{84}$ This "outsourcing" may provide brownfields developers with the state liability protection they seek, but provides no government's guarantee that they have undertaken proper remediation activities. ${ }^{85}$

Federal liability, of course, is another matter altogether. Before 2002, developers could obtain protection against state liability by completing remediation activities in VCPs, but there was no exemption from CERCLA liability. ${ }^{86}$ Even though states could not protect developers against federal liability, their releases were typically viewed as sufficient comfort to proceed with redevelopment activities. ${ }^{87}$ There was some federal activity on the liability front. States negotiated with the EPA to create memoranda of understanding that gave some protection to sites addressed in their VCPs without a full release from liability. ${ }^{88}$ The CERCLA innocent landowner defense and some federal programs, such as the EPA's guidance on "prospective purchaser agreements," provided limited protections. ${ }^{89}$

After the SBLRBRA's enactment in 2002, the prospect of CERCLA liability receded. The SBLRBRA provided a prospective purchaser exemption from CERCLA, which the EPA subsequently issued regulations to clarify. ${ }^{90}$ The EPA regulations require the prospective purchaser to allow access to and cooperate with regulators, ${ }^{91}$ and exercise care in dealing with the prior releases of contaminants at the site so as not to exacerbate the problem. $^{92}$ The new law also restricted actions under CERCLA against developers who remediate sites in VCPs. ${ }^{93}$

83. Site Remediation Program, N.J. DEP'T OF ENVTL. PROTECTION, http://www.state.nj.us/ dep/srp/ (last updated Oct. 9, 2012). See also Maro, supra note 20, at 181-82; EPA, STATE BROWNFIELDS AND VOLUNTARY RESPONSE PROGRAMS, supra note 8, at 16-17.

84. See Peterson, supra note 82, at 13-39 (describing the "commandments" for LSRPs).

85. See Maro, supra note 20, at 180-82; Rath, supra note 2, at 337.

86. See NAT'L ASS'N OF LOCAL GOV'T PROF'LS. \& NE.-MIDWEST INST., supra note 18, at 83.

87. See id.; Eisen, Brownfields of Dreams, supra note 16, at 950-58.

88. See BROWNFIELDS: A COMPREHENSIVE GUIDE, supra note 3, at 52; Eisen, Brownfields of Dreams, supra note 16 , at 964 n.348.

89. See BROWNFIELDS: A COMPREHENSIVE GUIDE, supra note 3, at 52; Eisen, Brownfields of Dreams, supra note 16 , at $982-83$.

90. See BROWNFIELDS: A COMPREHENSIVE GUIDE, supra note 3, at 83.

91. See 40 C.F.R. pt. 312 (2012).

92. See id.; Mintz, New Loopholes, supra note 5, at 406, 412; Schnapf, supra note 61, at 1011.

93. See Mintz, New Loopholes, supra note 5, at 420. 


\section{A COMPREHENSIVE APPROACH TO "FINALITY"}

The SBLRBRA provided liability protection, but did not bring finality to the brownfields problem. One challenge is simply that many sites have not been addressed. While large urban brownfields have been reused, other sites sit neglected. According to one recent estimate, states have only successfully dealt with $1 \%$ to $2 \%$ of all brownfields sites. ${ }^{94}$

A VCP traditionally deals with each site on its own, and remediation and reuse plans often have no requirement to relate to any comprehensive plan for urban redevelopment. ${ }^{95}$ There are exceptions to this, as some American cities eschew parcel-by-parcel redevelopment in favor of more systematic redevelopment approaches. ${ }^{96}$ However, finality demands a broader approach than is currently employed at many sites.

\section{A. Relationship to Smart Growth and Climate Action}

A brownfields project should fit within an overall plan of development for the affected community, with the community viewing the economic, environmental and institutional elements in a framework that considers all impacts and not just those of remediation. ${ }^{97}$ One problem, as noted above, is the parcel-specific nature of brownfields redevelopment. ${ }^{98}$ New York and New Jersey have area-wide brownfields initiatives, in which regulators attempt to address multiple brownfields in the same community. ${ }^{99}$ It has been noted that, "[i]n contrast to site-specific remediation, the area-wide approach of the [New Jersey] BDA provides a framework that addresses the

94. EVANS PaUll, ENVIRONMENTAL AND ECONOMIC BENEFITS OF BROWNFIELDS slide 11 (2009), available at http://www.nalgep.org/ewebeditpro/items/O93F18694.pdf.

95. Eisen, Brownfields Policies for Sustainable Cities, supra note 17, at 225, 227.

96. See, e.g., U.S. CONF. OF MAYORS, supra note 64, at 9.

97. See William SarNI, GREENING BrownFields: REMEdiation THROUGH Sustainable Development 84-85 (2009); Christopher DE SOUSA, BrownfieldS REDEVELOPMENT AND THE QUEST FOR SUSTAINABILITY 265-272 (2008) (Current Research in Urban and Reg'l Studies, vol. 3).

98. See supra notes $95-96$ and accompanying text.

99. D. Evan van Hook, et al., The Challenge of Brownfield Clusters: Implementing a MultiSite Approach for Brownfield Remediation and Reuse, 12 N.Y.U. ENVTL. L.J. 111, 113 (2003); Brownfield Opportunity Areas Program, N.Y. DePT. OF ENVTL. CONSERV., http://www.dec. ny.gov/chemical/8447.html; Brownfields Development Area (BDA) Initiative, N.J. DEP'T OF ENVTL. Prot., http://www.state.nj.us/dep/srp/brownfields/bda/. See Nicholas Capuano, Silent Blight: New York's Brownfields \& Environmental Justice, 20 PACE ENVTL. L. REV. 811,812 (2003). See also Maro, supra note 20, at 174-79 (discussing the BDA Initiative). 
larger physical, political and social contexts of an affected community." The EPA has called for more "area-wide planning among areas and corridors of brownfield sites," grants to develop area-wide plans. ${ }^{102}$

In one encouraging development, there are active links between the "smart growth" movement and brownfields redevelopment." 103 "Smart growth" refers to the myriad of "creative strategies to develop in ways that preserve natural lands and critical environmental areas, protect water and air quality, and reuse already-developed land," which stand in opposition to the existing patterns of "sprawl"-centered development. ${ }^{104}$ However, the fact that brownfields projects use existing urban land and, at times, some existing infrastructure, does not necessarily make that growth "smart."105

There are many opportunities for smart reuse of brownfield sites that would not only conserve greenfields acreage but also deploy green technologies to reduce carbon emissions and produce other benefits. ${ }^{106}$ Some sites have been transformed into urban greenways. ${ }^{107}$ An intriguing new use of brownfields sites is for renewable energy facilities, ${ }^{108}$ including so-called "brightfields"109 locating solar panel arrays and wind turbines at

100. Kris Wernstedt \& Jennifer Hanson, Areawide Brownfield Regeneration Through Business-Based Land Trusts and Progressive Finance, LINCOLN INST. OF LAND POL'Y, 7 (2006), available at http://www.lincolninst.edu/pubs/d1/1096_Wernstedt_complete_web.pdf.

101. EPA, Brownfields Benefits, supra note 38.

102. Brownfields Area-Wide Planning Pilot Program, U.S. EPA, http://www.epa.gov/ brownfields/areawide grants.htm.

103. See Patricia E. Salkin, Smart Growth and Sustainable Development: Threads of a National Land Use Policy, 36 VAL. L. REV. 381, 391-92, 396-97 (2002); Smart Growth and Brownfields, U.S. EPA, http:/www.epa.gov/piedpage/brownfields.htm.

104. See About Smart Growth, U.S. EPA, http://www.epa.gov/smartgrowth/about_sg.

htm; Sustainability Depends on Curbing Urban Sprawl, Resource Drain and Overall Waste, SMART GROWTH ONLINE, http://www.smartgrowth.org/engine/events.php/2010/news-26.

105. Eisen, Brownfields at 20, supra note 3, at 749-50.

106. See SARNI, supra note 97, at 86; PETER CALTHORPE, URBANISM IN THE AGE OF Climate Change 106 (2010); Greg Lewis, Brown to Green: Sustainable Redevelopment of America's Brownfield Sites, NE.-MIDWEST INST.: CENT. FOR POL'Y INITIATIVES, http://www.nemw.org/images/issues/brownfields/2008-12-26\%20-

$\% 20$ Green $\% 20$ brownfield $\% 20$ issue $\% 20$ brief.pdf.

107. Hollander et al., PRinciples of Brownfields Regeneration, supra note 19, at 86 (discussing the Assunpink Greenway in Trenton, $\mathrm{NJ}$ ).

108. See Uma Outka, The Renewable Energy Footprint, 30 STAN. ENVTL. L.J. 241, 281-82, 299-301 (2011); Steven Ferrey, Converting Brownfield Environmental Negatives into Energy Positives, 34 B.C. ENVTL. AFF. L. REV. 417 (2007); Hannah Wiseman, Expanding Renewable Regional Governance, 35 HARV. ENVTL. L. REV. 477, 510 (2011).

109. Hollander et al., Principles of Brownfields Regeneration, supra note 19, at 54-55. 
urban sites. ${ }^{110}$ Using green design and construction techniques in overhauling existing buildings at a brownfields site may conserve energy and feature sustainable building materials and creative waste reduction strategies. ${ }^{111}$ The LEED certification system for sustainable buildings awards points for building on a brownfields site, and adds points for variables like building close to existing transportation systems. ${ }^{112}$

An evolving long-term trend involves planning activities that explicitly connect brownfields with actions to address climate change. ${ }^{113}$ Local sustainability or environmental quality departments are integrating brownfields redevelopment with community-wide land use planning efforts. ${ }^{114}$ Climate action plans (such as those developed in Portland and Cincinnati, which discuss the role of brownfields redevelopment ${ }^{115}$ ) can be excellent tools for integrating brownfields redevelopment planning in a city's climate change response.

Although there has been much progress in this area at brownfields sites, "there is still room and need for further experimentation and implementation of sustainable and green methodologies." 116 That could serve as a summary of the relationship between greentech and brownfields redevelopment at present: much has been accomplished, but there are still considerable opportunities. Some form of evaluative approach will also be necessary to determine whether brownfields policies meet the criteria outlined in climate action plans. ${ }^{17}$

110. Abby Gruen, N.J. Senate passes rule for solar and wind development on brownfields, NJ.COM (Aug. 23, 2010, 5:05 PM), http://www.nj.com/business/index.ssf/2010/08/ nj_senate_passes_rule_for_sola.html; Brockton Brightfields, CITY OF BROCKTON, http://www. brockton.ma.us/government/departments/Planning/BrocktonBrighfields.aspx (describing the Brockton Gas Works project).

111. See, e.g., LEED Green Building Rating Systems, U.S. GREEN BUILDNG COUNCIL, https://new.usgbc.org/leed/rating-systems; Green Building, U.S. ENVTL. PROT. AGCY., http:// www.epa.gov/greenbuilding/.

112. LEED Green Building Rating Systems, supra note 111.

113. See Paull, supra note 94, at slide 17.

114. One of many examples is Asheville, North Carolina's Office of Sustainability. See Sustainability, CITY OF ASHEVILLE, N.C: OfFICE OF SUSTAINABILITY, http://www.ashevillenc. gov/Departments/Sustainability.aspx.

115. See City of Portland and Multnomah County Climate Action Plan 2009, CITY OF PORTland BUREaU OF PlanNing AND SUSTAINABILITY, (Oct. 2009), http://www. portlandoregon.gov/bps/article/268612; Climate Protection Action Plan: The Green Cincinnati Plan, CITY OF CINCINNATI, 201-02 (Jun. 19, 2008), http://www.cincinnati-oh.gov/ oeq/assets/File/climate_protection_action_plan.pdf.

116. Lewis, supra note 106 , at 15.

117. Ronell Auld et al., Assessing Brownfield Sustainability: Life Cycle Analysis and Carbon Footprinting, W. PA. BROWNFIELDS CTR., (2011), http://www.cmu.edu/steinbrenner/brownfields/ Current\%20Projects/sustainability.html. 


\section{B. Community Participation}

Brownfields remediation and reuse often "dramatically impact[s] the health and economy of the nearby communities," 118 and community planners have therefore viewed participation of the affected community as critical to a brownfields project's success. ${ }^{119}$ As one report observes, "Community involvement and consensus is one of the most important ingredients for a successful brownfield project." 120 Different actors may have diverging ideas about the ideal plan for transforming an urban brownfield site, ${ }^{121}$ and public involvement in the process can bring a wider focus on community redevelopment than that of a developer. ${ }^{122}$ Discussing a number of successful projects since the 1990s, the EPA has observed that, "By creating a dialogue among all stakeholders in a brownfields project, community engagement enhances the final reuse of the property and the long-term success of the project." ${ }^{23}$ Public participation in brownfields redevelopment also recognizes the central concern of environmental justice advocates ${ }^{124}$ that sites are often in areas of cities where residents have "traditionally been left out of the planning process," 25 and community outreach can address the political marginalization of these residents.

Yet to many developers, economic concerns are paramount. ${ }^{126}$ For this reason, the initial design of many VCPs empowered developers to fix the extent of public input in decision-making at brownfields sites. ${ }^{127}$ This is a sharp distinction between this process and the CERCLA model, where extensive public participation in cleanup activities is mandatory. ${ }^{128}$

118. Building Capacity: Brownfields Redevelopment for Community-Based Organizations, NAT'L. CTR. FOR NEIGHBORHOOD \& BROWNFIELDS REDEVT, I-1 (Apr. 2008).

119. Daniel M. Speiss, Public Participation in Brownfields Cleanup and Redevelopment: The Role of Community Organizations, 1-2 (2008) (Ph.D. dissertation, University of Michigan), http://deepblue.lib.umich.edu/bitstream/2027.42/60850/1/dspiess_1.pdf. See EPA, STATE BROWNFIELDS AND VOLUNTARY RESPONSE PROGRAMS, supra note 8, at 12, 17; U.S. CONF. OF MAYORS, supra note 64, at 9, 10.

120. NAT'L ASS'N OF LOCAL GOV'T PROF'LS. \& NE.-MIDWEST INST., supra note 18, at 6.

121. See Eisen, Brownfields Policies for Sustainable Cities, supra note 17, at 202.

122. See SARNI, supra note 97 , at 84-85.

123. Building Vibrant Communities: Community Benefits of Land Revitalization, U.S. ENVTL. Prot. AGCY., 2 (Oct. 2009), http://www.epa.gov/brownfields/policy/comben.pdf.

124. Eisen, Brownfields Policies for Sustainable Cities, supra note 17, at 219-229 (discussing the link between brownfields and environmental justice, and proposing solutions such as "Community Working Groups").

125. Speiss, supra note 119 , at 35 .

126. WERNSTEDT ET AL., THE BROWNFIELDS PHENOMENON, supra note 26 , at 4-5.

127. See Eisen, Brownfields of Dreams, supra note 16, at 998, 1000, 1002-03, 1005, 1008.

128. 42 U.S.C. $\$ 9617$ (2011) (describing the public participation requirements). 
Although VCPs do not typically require public participation, developers are increasingly working with affected communities to garner support for individual projects. ${ }^{129}$ Unfortunately, even when developers conduct public meetings or other means of involvement, the level of participation can fall far short of meaningful input. ${ }^{130}$ In many cities, there are no obvious stakeholders to voice concerns of residents near brownfields sites, let alone engage in discussions with developers that have already committed to moving projects forward. ${ }^{131}$ Designating or forming a citizen "steering committee" or other community-based group can lead to enhanced public participation and a wider focus on community redevelopment, particularly if that organization is an existing group that has knowledge and expertise in the affected community. ${ }^{132}$ Regardless of the means chosen to provide for public input, the challenge remains at many sites and in many cities to allow affected communities to have a meaningful say in the future of brownfields projects. ${ }^{133}$

\section{Evaluation of Site and Program Results}

In 2011, news reports pointed to numerous shortcomings in the New Jersey Department of Environmental Protection's (DEP) assessments of the 1,600 sites awarded grants under the state's fund for brownfields remediation. $^{134}$ Officials did now know, for example, whether the sites had ever been developed for the specific purposes identified in the grants. ${ }^{135}$ The DEP's Commissioner subsequently criticized these reports, calling the program a "national model" and stating that, "the DEP and EDA closely track exactly how much HDRSF money is being spent on each brownfields project through a rigorous process that includes thorough technical and financial reviews." ${ }^{136}$ This fell short of addressing all of the critics' claims, and highlighted a larger problem present in New Jersey and many other

129. See Eisen, Brownfields at 20, supra note 3, at 224.

130. Speiss, supra note 119 , at 32. See SARNI, supra note 97 , at 85 .

131. See BROWNFIELDS: A COMPREHENSIVE GUIDE, supra note 3, at 282

132. See Hollander et Al., Principles of Brownfields Regeneration, supra note 19, at 88; NAT'L CTR. FOR NEIGHBORHOOD \& BROWNFIELDS REDEVELOPMENT, supra note 118, at I1.

133. BROWNFIELDS: A COMPREHENSIVE GUIDE, supra note 3, at 283.

134. Christopher Baxter, N.J. officials didn't track the $\$ 281 M$ spent from brownfields fund to clean polluted properties, NJ.COM (July 31, 2011, 6:00 AM), http://www.nj.com/news/ index.ssf $/ 2011 / 07 /$ nj_officials_say_they_failed_t.html.

135. Id.

136. Bob Martin \& Caren Franzini, Turning N.J. brownfields green again, NJ.COM (Aug. 15, 2011 7:24 AM), http://blog.nj.com/njv_guest_blog/2011/08/turning_nj_brownfields_green_a. html. 
states: while a large number of projects have been processed through state VCPs, there is little adequate analysis of the results. ${ }^{137}$ The VCP process focuses on the present day problem of transforming an abandoned or underused site into a locus for commerce, and, as a result, has not focused on impacts of site redevelopment after initial remediation and reuse activities. $^{138}$

To date there has not been much "systematic, careful documentation of actual practice at a wide range of [brownfield] sites," 139 and states do not have formal processes in place to evaluate sites over time. ${ }^{140}$ Years after VCPs have been operating, research is finally underway to assess long-term impacts, ${ }^{141}$ but adequate methodologies are not in place. In particular, it has been noted that, "methods and estimates for quantifying life cycle impacts, especially climate change mitigation associated with Brownfield development, do not currently exist." ${ }^{142}$ States should do more to address this shortcoming of understanding the impacts of brownfields redevelopment in affected communities.

\section{Public Investment in Brownfields Sites: Critical But Often Lagging}

In a high-profile "miss," the New Jersey DEP announced in summer 2011 that the fund it administers to provide funding for assessment and remediation of brownfields sites had run out of money. ${ }^{143}$ Projects in the

137. See SHAW ET AL., supra note 37, at iii.

138. See W. Pa. Brownfields Ctr., About the Western Pennsylvania Brownfields Center, CARNEGIE MELLON UNIV,, http://www.cmu.edu/steinbrenner/brownfields/About/index.html; WERNSTEDT ET AL., THE BROWNFIELDS PHENOMENON, supra note 26, at 18.

139. NAT'L ASS'N OF LOCAL GOV'T PROF'LS. \& NE.-MIDWEST INST., supra note 18, at 9-10; WERnstedt ET AL., THE Brownfields PhenOMENON., supra note 26, at 1 . See Richard C. Hula \& Rebecca Bromley-Trujillo, Cleaning Up the Mess: Redevelopment of Urban Brownfields, 24 ECON. DEV'T Q. 276 (2010) ("Although [brownfields] programs are often perceived as having a positive impact, there is remarkably little evidence beyond anecdotal examples to support such claims.").

140. See Auld et al., supra note 117; WERNSTEDT ET AL., THE BROWNFIELDS PHENOMENON, supra note 26 , at 6.

141. SHAW ET AL., supra note 37, at iii (listing specific proposals relating to measuring impacts of brownfields projects in New Jersey).

142. W. Pa. Brownfields Ctr., Assessing Brownfields Sustainability, CaRnEgIE MeLloN UNIV., http://www.cmu.edu/steinbrenner/brownfields/Current\%20Projects/sustainability.html.

143. The fund in question is New Jersey's Hazardous Discharge Site Remediation Fund (HDSRF), funded through a business tax. Baxter, N.J. to shut down state initiative, supra note 22; Hazardous Discharge Site Remediation Fund, N.J. DEP'T OF ENVTL. PROT., (last updated June 27, 2011), http://www.nj.gov/dep/srp/finance/hdsrf/. 
pipeline totaling $\$ 71$ million were suspended, leaving their future in doubt. ${ }^{144}$

This highlights a major challenge of current brownfields policy. Public support (including funding for site assessment and other purposes) is often critical for the success of brownfields redevelopment. ${ }^{145}$ Initiatives at all levels of government target remediation and social, economic, institutional, and other aspects of brownfields reuse. ${ }^{146}$ Public involvement begins at the very start of the process. In many communities, interest in brownfields is low, and this is especially true for small brownfields or those in cities with "little interest from developers and a lack of knowledge on how to proceed with redevelopment." 147 Localities and prospective developers interested in brownfields reuse often must also address capacity and management issues. $^{148}$ Developers can find the brownfields redevelopment process overly complex. ${ }^{149}$ Matching developers with opportunities to remediate and reuse brownfields requires careful planning, for example, by employing marketing approaches and designating local officials as contact points to navigate complex approval processes. ${ }^{150}$

Public funding can be an important factor in a project's success. Developers can obtain resources for a site's evaluation, remediation and reuse from a wide variety of federal and state agencies. ${ }^{151}$ As Table 1 indicates, state grant, loan, training and education programs, and tax and other financing incentives support brownfields redevelopment. ${ }^{152}$ At the federal level, the EPA implemented the SBLRBRA with federal grants and

144. Baxter, N.J. to shut down state initiative, supra note 22; Broke Brownfield Fund is Bad Policy, says Sierra Club, NJTODAY.NET, (June 16, 2011), http://njtoday.net/2011/06/16/brokebrownfield-fund-is-bad-policy-says-sierra-club/.

145. See Broke Brownfield Fund is Bad Policy, says Sierra Club, supra note 144.

146. SARNI, supra note 97 , at 42-43.

147. W. Pa. Brownfields Ctr., USEPA Training, Research, and Technical Assistance Project, CARNEGIE MELLON UNIV., http://www.cmu.edu/steinbrenner/brownfields/epa-lca-project/index. html. 66.

148. Hollander et al., Principles of Brownfields Regeneration, supra note 19, at

149. Catherine Finneran, Attracting Development to Brownfields Sites: A Local Challenge, PUB. MGMT. MAG., Nov. 2006, available at http://webapps.icma.org/pm/8810/public/cover.cfm? author=Catherine $\% 20$ Finneran\&title=Attracting $\% 20$ Development $\% 20$ To $\% 20$ Brownfields $\% 20$ Sit es\%3A\%20A\%20Local\%20Challenge\&subtitle.

150. Id.

151. Charles Bartsch, Financing Brownfield Cleanup and Development, GoverNMENT FINANCE REVIEW, 27 (February 2002), http://www.gfoa.org/downloads/FinancingBrownfield CleanupandRedevelopment_000.pdf (describing available federal and state resources).

152. HOLlander ET AL., PRINCIPLES OF BROWNFIELDS REgENERATION, supra note 19, at 13-14. 
other tools to address brownfields sites. ${ }^{153}$ These resources include grant programs for characterization of brownfields sites, and site analytical tools that can help make the process of environmental investigation and remediation less onerous and costly. ${ }^{154}$ The EPA's Brownfields Assessment Grants are available to "inventory, characterize, assess, and conduct planning and community involvement related to brownfields sites." 155 Once a site has been selected for analysis, the use of comprehensive site analytical tools such as the EPA's Triad approach can streamline environmental investigation and cut remediation costs. ${ }^{156}$ The EPA's brownfields website cites a number of redevelopment "Success Stories" linked to its brownfields programs. ${ }^{157}$

Other federal agencies support site redevelopment activities, ${ }^{158}$ and agencies are teaming together to address brownfields, with the HUD-DOTEPA Interagency Partnership for Sustainable Communities (formed in 2009) serving as a notable example. ${ }^{159}$ Federal programs on infrastructure and housing and community development are adapting to promote site redevelopment and reuse. ${ }^{160} \mathrm{~A}$ particular focus is the link between brownfields redevelopment and economic growth. ${ }^{161}$ Brownfields Job Training Grants, part of the $\$ 100$ million that the American Recovery and Reinvestment Act made available to the EPA, ${ }^{162}$ are an example of this trend. Brownfields redevelopment is a source of "green jobs," linking

153. Brownfields and Land Revitalization, U.S. EPA (Feb. 3, 2011), http://web.archive.org/ web/20110203132536/http:/www.epa.gov/brownfields/about.htm (accessed by searching for www.epa.gov/brownfields/about.htm in the Internet Archive index).

154. Id.

155. Assessment Pilots/Grants, U.S. EPA, (last updated Sept. 29, 2010), http://epa.gov/ brownfields/assessment_grants.htm.

156. See Brownfield Site Contamination Investigation, supra note 81, at 5 ("The Triad approach is useful for Brownfield sites because it considers the whole site (not just Area of Concern focuses), [and] is flexible (can be adjusted to unexpected conditions) and integrates all stakeholders into the site decision making process ....").

157. Brownfields Success Stories, U.S. EPA, (last updated Mar. 9, 2012), http://www.epa.gov/ swerosps/bf/success/.

158. HOLLANDER ET AL., PRINCIPLes OF BROWNFIELdS REgENERATION, supra note 19 , at 13.

159. HUD-DOT-EPA Partnership for Sustainable Communities, U.S. EPA (last updated Sept. 18, 2012), http://www.epa.gov/smartgrowth/partnership/index.html.

160. See SARNi, supra note 97 , at 57.

161. Id. at 57-58.

162. Of the $\$ 100$ million available under the ARRA, the EPA used $\$ 6.8$ million for job training. Brownfields Program Activities Under the Recovery Act, U.S. EPA (last updated April 5, 2012), http://www.epa.gov/brownfields/eparecovery/; Legislation \& Policy: Stimulus Status Report, NAT'L BROWNFIELD ASS'N, http://www.brownfieldassociation.org/News/Default. aspx\#Congress. 
greentech such as renewable energy sources and green building construction with job creation. ${ }^{163}$

Table 1

Selected Brownfields Financial Assistance Programs ${ }^{164}$

\begin{tabular}{|c|c|c|c|}
\hline Program/Incentive & $\begin{array}{c}\text { Level of } \\
\text { Government }\end{array}$ & Description & Notes \\
\hline $\begin{array}{l}\text { Brownfields } \\
\text { Expensing } \\
\text { Tax Incentive }\end{array}$ & Federal & $\begin{array}{l}\text { Allows the developer } \\
\text { to deduct } \\
\text { environmental } \\
\text { cleanup costs in the } \\
\text { year that they are } \\
\text { incurred, rather than } \\
\text { capitalize them over } \\
\text { time }\end{array}$ & $\begin{array}{l}\text { Reauthorized } \\
\text { through } \\
\text { December, } 2011\end{array}$ \\
\hline $\begin{array}{l}\text { Historic } \\
\text { Rehabilitation } \\
\text { Tax Credits }\end{array}$ & Federal & $\begin{array}{l}\text { Tax credits for } \\
\text { restoration of } \\
\text { certified historic } \\
\text { properties \& for } \\
\text { rehabilitation of non- } \\
\text { certified sites }\end{array}$ & $\begin{array}{l}\$ 4.7 \text { billion in } \\
\text { work at } 1,044 \\
\text { sites in } 2009 \\
\text { (Source: National } \\
\text { Park Service) }\end{array}$ \\
\hline $\begin{array}{l}\text { Tax-increment } \\
\text { Financing (TIF) } \\
\text { guarantees }\end{array}$ & States & $\begin{array}{l}\text { Guarantees stream of } \\
\text { increased property } \\
\text { taxes that repay TIF } \\
\text { bonds }\end{array}$ & $\begin{array}{l}\text { Example: } \\
\text { Pennsylvania TIF } \\
\text { Guarantee } \\
\text { Program }\end{array}$ \\
\hline
\end{tabular}

163. SARnI, supra note 97, at 58. See VAN JONES, THE GREEN COLLAR ECONOMY 191 (2008) (discussing this trend).

164. This Table is derived from programs described in A Guide to Federal Tax Incentives for Brownfields Redevelopment, U.S. EPA (2011), www.epa.gov/brownfields/tax/tax_guide.pdf [hereinafter EPA Tax Incentives] 


\begin{tabular}{|c|c|c|c|}
\hline $\begin{array}{l}\text { Bond, loan and/or } \\
\text { grant funding }\end{array}$ & States & $\begin{array}{l}\text { Direct funding } \\
\text { programs that differ } \\
\text { depending on the } \\
\text { state }\end{array}$ & $\begin{array}{l}\text { Examples: } \\
\text { Low-interest } \\
\text { cleanup loans } \\
\text { (Delaware, } \\
\text { lndiana, and } \\
\text { Wisconsin); } \\
\text { Remediation } \\
\text { grant funds (New } \\
\text { Jersey }{ }^{165} \text { and } \\
\text { Minnesota) }\end{array}$ \\
\hline Other programs & Federal/state & $\begin{array}{l}\text { Programs designed } \\
\text { for other purposes } \\
\text { that can be used for } \\
\text { brownfields sites }\end{array}$ & $\begin{array}{l}\text { Examples: State } \\
\text { Clean Water } \\
\text { Revolving Loan } \\
\text { Funds; renewable } \\
\text { energy incentive } \\
\text { programs }\end{array}$ \\
\hline
\end{tabular}

The availability of public funding can be critical to brownfields redevelopment, and project success often "depends on the extent that public investments leverage private funds." $"$ Public funding is especially important when site assessment and remediation costs exceed current property values, ${ }^{167}$ which front-loads the developer's investment. ${ }^{168}$ As the New Jersey program's shortfall illustrates, continued public investment is not always guaranteed in the current tight budgetary climate. ${ }^{169}$ This is a serious threat to future brownfields remediation and reuse projects.

165. In New Jersey, these funds come from the HSDRF, the program underfunded in 2011. Hazardous Discharge Site Remediation Fund, supra note 143.

166. See EPA, INVESTING IN PARTNERSHIP, POSSIBILITY, AND PEOPLE, supra note 6, at 33. See also U.S. CONF. OF MAYORS, supra note 64, at 11 ("Cities were asked to identify the most useful tools to redevelop brownfield sites. The top four, in order, were: EPA Assessment Funding, Private Sector Investment, EPA Clean-Up Funds, and State programs such as the State Voluntary Clean-Up Programs.").

167. NAT'L ASS'N OF LOCAL GOV'T PROF'LS. \& NE.-MIDWEST INST., supra note 18, at 5.

168. See U.S. CONF. OF MAYORS, supra note 64, at 11; EPA, INVESTING IN PARTNERSHIP, POSSIBILITY, AND PEOPLE, supra note 6, at 33-34.

169. EPA Tax Incentives, supra note 164, at 24; NAT'L ASS'N OF LOCAL GOV'T PrOF'LS. \& NE.-MIDWEST INST., supra note 18, at 7. 


\section{E. Oversight ... After All These Years}

Brownfields remediation activities do not eliminate all risks, in part due to relaxed cleanup standards. As the brownfields history grows longer, there may be problematic sites if states do not have aggressive provisions for revisiting cleanups. ${ }^{170}$ The efficacy of some brownfields cleanups has come under fire years afterwards as contamination has been discovered. ${ }^{171}$ In one notorious example in New Jersey, the "Kiddie Kollege" day care center built on a former brownfield turned out to be situated on contaminated land. ${ }^{172}$

States typically protect against backsliding with reopeners in VCPs that allow state environmental departments to require additional cleanup activities at a later date if changed conditions warrant it. ${ }^{173}$ These reopeners have several drawbacks. In a system such as New Jersey's post-2009 Site Remediation Program, the state has no involvement with the site in its initial cleanup, ${ }^{174}$ so it is unlikely to be vigilant in discovering postremediation flaws. Also, reopeners in VCPs tend to be limited to intervening to prevent imminent harm, as any broader provision is typically perceived as a deterrent to the initial entry into a VCP (although one empirical study has found that few sites are reopened and the fear is largely unwarranted $^{175}$ ).

One study suggests that "reopener rates may increase with more vigorous enforcement and over the passage of time," 176 but it seems more likely that fewer sites will be addressed in the future. Any reopener provision depends both on resources available in the future to state environmental agencies, and on the willingness of those agencies to tackle problems at sites they believed were successfully addressed in the past. The problem of resources to devote to enforcement is especially problematic in tight budgetary climates, as cutbacks in state budgets can lead to a slower

170. WERNSTEDT ET AL., THE BROWNFIELDS PHENOMENON, supra note 26, at 2, 12 (noting that "more opportunities for reopeners will arise as site histories lengthen at voluntarily remediated sites"); Pendergrass, supra note 63, at 1308-09 (discussing the need to audit sites with institutional controls).

171. See Eisen, Brownfields Policies for Sustainable Cities, supra note 17, at 216-217.

172. Rath, supra note 2, at 338-39, and Eisen, Brownfields at 20, supra note 3, at 744-45, discuss this and other sites involving the New Jersey site remediation programs.

173. See John Pendergrass et al., Quantifying Long-Term Environmental Regulatory Risk for Brownfields: Are Reopeners Really an Issue?, 46 J. ENVTL. PLAN. \& MGMT. 257 (2003).

174. See Maro, supra note 20 , at 159.

175. See Pendergrass et al., supra note 173, at 257 (noting that "among the 46 states with VCPs, only 12 cases were reopened out of 11,497 closed environmental cases, a reopener rate of between $0.1 \%$ and $0.2 \% "$ ).

176. Id. 
pace of cleanups and less vigilant oversight of brownfields sites. ${ }^{177}$ State environmental agencies have been paring back the resources they devote to enforcement generally, and New Jersey is no exception. ${ }^{178}$ With limited resources, few state environmental agencies will prioritize oversight and monitoring of completed brownfields sites ahead of ongoing enforcement actions.

\section{CONCLUSION}

"Finality" is elusive in brownfields redevelopment. Decades after their inception, brownfields redevelopment programs are mature environmental programs with many successes. However, closing the book on brownfields means much more than simply assessing whether remediation at some individual brownfields sites has been successful. Given the original preoccupation with shining a light on these neglected sites and getting them back into the stream of commerce, finality would mean that all of them have been inventoried, investigated, and remediated if needed. Moreover, the focus on initial cleanups comes at the expense of monitoring sites and assessing long-term results, all of which need increased attention. If states discover contamination more significant than originally present, they must address it. In addition, major societal developments in the two decades since "brownfields" first entered the nation's vocabulary, particularly the growth of the environmental justice movement and the increased focus on addressing climate change, have shown the limitations of VCPs' parcel-byparcel, developer-centered approach.

The specter of federal liability may be less significant than it once was, and VCPs have been responsible for many successes, but the final verdict on brownfields programs has yet to be rendered.

177. See EPA, StaTe BROWNFIELdS AND VoluntaRY Response Programs, supra note 8, at 1; Eisen, Brownfields Policies for Sustainable Cities, supra note 17, at 216.

178. Rath, supra note 2, at $342-43$ (describing the funding cutbacks and deregulatory legislation that have decreased the state's role in waste remediation). 
